\title{
Preparation, Spectral and Thermal Decomposition Characteristics of Chromium Complexes of Phthalic Acid
}

\author{
M. K. MISHRA \\ Department of Chemistry, BIT Sindri, Dhanbad, Jharkhand, India \\ mkmishrabit@gmail.com
}

Received 5 June 2015 / Accepted 26 June 2015

\begin{abstract}
Complexes $\left[\mathrm{Cr}\left(\mathrm{C}_{8} \mathrm{H}_{5} \mathrm{O}_{4}\right)(\mathrm{OH})_{2}\left(\mathrm{H}_{2} \mathrm{O}\right)_{3}\right]$ and $\left[\mathrm{Cr}\left(\mathrm{C}_{8} \mathrm{H}_{5} \mathrm{O}_{4}\right)(\mathrm{OH})_{2}\left(\mathrm{H}_{2} \mathrm{O}\right)_{3}\right] \mathrm{H}_{2} \mathrm{O}$ were prepared by using chromium trioxide $\left(\mathrm{CrO}_{3}\right)$ and phthalic acid. (Hereafter these phthalic acid complexes $\left(\mathrm{Cr} / \mathrm{H}_{2} \mathrm{Pht}\right)$ will be named as $\mathrm{Cr} / \mathrm{H}_{2} \mathrm{Pht} 1$ and $\mathrm{Cr} / \mathrm{H}_{2} \mathrm{Pht} 2$ respectively). Their spectral characterization was done by using elemental analysis (C and $\mathrm{H})$, ICP-OES, UV-Vis spectroscopy, FTIR spectroscopy, ${ }^{1} \mathrm{H}$ NMR and Fast Atomic Bombardment (FAB) Mass spectrometry, whereas thermal decomposition was investigated by differential scanning calorimetric (DSC). Study includes thermal decomposition kinetics and lability nature of the complexes prepared.
\end{abstract}

Keywords: Chromium complexes, Lability nature, Thermal decomposition, Phthalic acid

\section{Introduction}

Hexavalent chromium is a powerful oxidant and finds a number of applications in organic synthesis. Reactions of chromium (VI) with oxygen-, nitrogen- and sulphur -containing reductants have been the subject of several investigators ${ }^{1-3}$. In some instances the formation of oxygen-, nitrogen- and sulphur- chromium(VI) bonded intermediates have been proposed. The complexing agents (picolinic acid), organic acid (oxalic acid) and transition metal ions have some effect on reduction rate of chromium(VI) by different organic reductants. Chromium has several different oxides, amongst them $\mathrm{Cr}_{2} \mathrm{O}_{3}, \mathrm{CrO}_{2}$ and $\mathrm{CrO}_{3}$ are of special significance. Chromium trioxide $\left(\mathrm{CrO}_{3}\right)$ dissolves in water, acetic anhydride, $t$-butyl alcohol, pyridine etc. and reacts vigorously with organic substances is widely used as an oxidant in synthetic organic chemistry. Chromium(III) is found to be an efficient catalyst (especially in alkaline medium) which catalyses the reaction with a measurable velocity ${ }^{4-7}$.

Complexes in which ligands can be replaced by other ligands in order to reach greater stability are divided into two groups. Complexes in which ligands are rapidly replaced by other are called labile complexes and those in which ligand substitution is slow are called inert complexes. Also, a complex is called inert, if the activation energies $\left(E_{a}\right)$ of the formation 
and decomposition reactions are large. It has been also reported that the covalent coordinate bond having energy 20-80 kcal/mol (83-334 kJ/mol) with first row metal-ligand bond show high stability with high lability, with the second row metal ligand bond show high stability and medium lability while with the third row metal-ligand bond show high stability and low lability ${ }^{8}$.

Thus it was thought of interesting to prepare and characterize complexes by using $\mathrm{CrO}_{3}$ and phthalic acids. The spectral and thermal behavior of these complexes has also been investigated and the results are discussed in this paper.

\section{Experimental}

Phthalic acid from s.d. fine-chem, Chromic acid $\mathrm{CrO}_{3}$ from Apex chemicals and ethyl alcohol from Merck were used as received.

\section{Preparation of complexes}

An aqueous solution of different molar concentration $\mathrm{CrO}_{3}$ (dissolved in water) mixed with ethanolic solution with different molar concentration of phthalic acid. The resulting solution was refluxed for 30 min after which time a suspension had formed. It was filtered and solid was washed with ethanol and dried in air. Details of sample and their identification are summarized in Table 1.

Table 1. Details of samples and their identification

\begin{tabular}{ccccc}
\hline \multirow{2}{*}{ Sample ID } & $\begin{array}{c}\mathrm{CrO}_{3}: \text { phthalic acid : } \\
\text { solvent (molar ratio) }\end{array}$ & $\begin{array}{c}\text { Amount taken, g } \\
\mathrm{CrO}_{3}: \text { phthalic acid. }\end{array}$ & Colour & Yield \\
\hline $\mathrm{Cr} / \mathrm{H}_{2} \mathrm{Pht} 1$ & $\mathrm{CrO}_{3}: \mathrm{H}_{2} \mathrm{Pht}: \mathrm{H}_{2} \mathrm{O}(1: 1)$ & $1: 1.66$ & Light green & $0.73 \mathrm{~g}, 43 \%$ \\
$\mathrm{Cr} / \mathrm{H}_{2} \mathrm{Pht} 2$ & $\mathrm{CrO}_{3}: \mathrm{H}_{2} \mathrm{Pht}: \mathrm{H}_{2} \mathrm{O}(1: 2)$ & $1: 3.23$ & Blue-green & $2.38 \mathrm{~g}, 55 \%$ \\
\hline
\end{tabular}

Analysis of metal complexes

Elemental analysis $(\mathrm{C} \& H)$

Elemental analysis(C\&H) done at Sophisticated Analytical Instrument Facility (SAIF), Central Drug Research Institute, Lucknow, India. Inductively coupled plasma optical emission spectroscopy (ICP-OES): ICP-OES were recorded on Perkin Elmer 5300 DV (Dual view), diluted in acids, Plasma of Argon is the source, at Sophisticated Analytical Instrument Facility (SAIF), Indian Institute of Technology, Madras, India. Elemental data of chromium complexes are given in Table 2.

Table 2. Elemental data of complexes

\begin{tabular}{lcccc}
\hline Complexes & \multicolumn{4}{c}{ elemental analysis, \% observed (calculated) } \\
\hline & \multicolumn{2}{c}{$\mathrm{C}$} & $\mathrm{H}$ & $\mathrm{Cr}$ \\
\hline $\mathrm{Cr} / \mathrm{H}_{2} \mathrm{Pht} 1$ & 30.89 & $(31.48)$ & $4.10(4.26)$ & $16.37(17.05)$ \\
$\mathrm{Cr} / \mathrm{H}_{2} \mathrm{Pht} 2$ & 30.28 & $(29.72)$ & $4.84(4.64)$ & $16.81(16.10)$ \\
\hline
\end{tabular}

\section{UV-Vis spectrophotometry}

UV-VIS spectra recorded on ECIL, Hyderabad, Double beam spectrophotometer UV5704SS, in the range 200-650 nm in the Department of Applied Chemistry, Indian School of Mines University, Dhanbad, India

The UV-Vis spectra of chromium complexes in DMSO are shown in Figure 1-2. Table 3 gives consolidated values of the peaks (along with absorbance) of these spectra. 


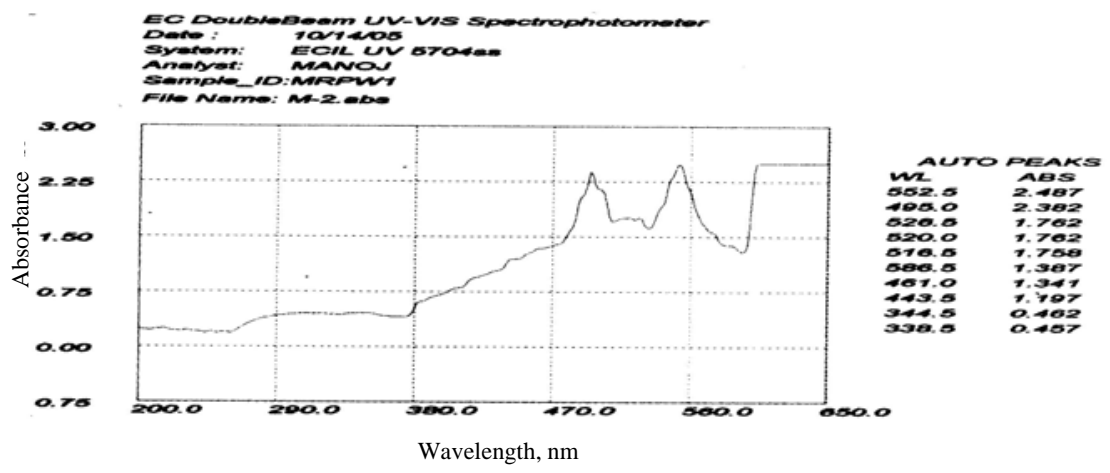

Figure 1. UV-Vis spectrum of $\mathrm{Cr} / \mathrm{H}_{2} \mathrm{Pht} 1$

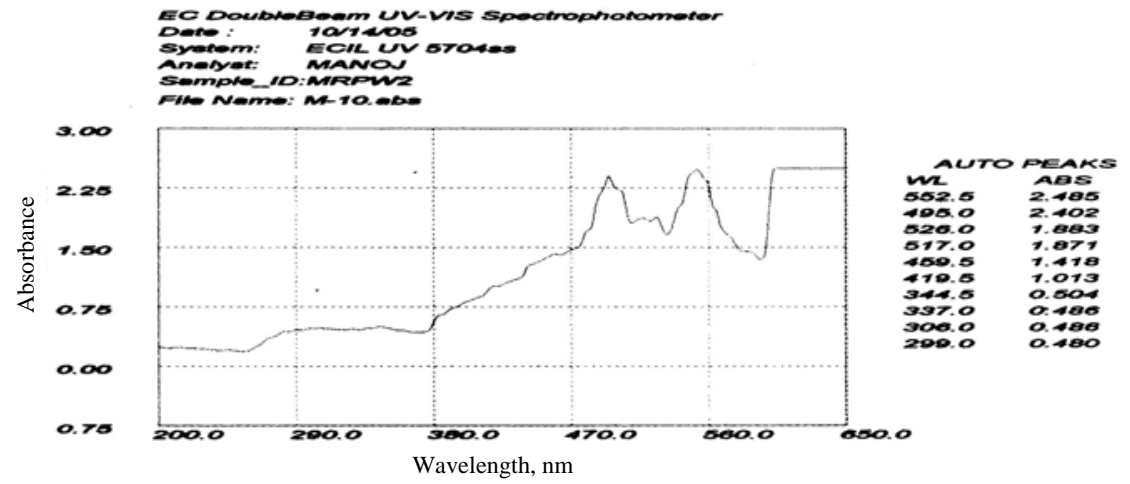

Figure 2. UV-Vis spectrum of $\mathrm{Cr} / \mathrm{H}_{2} \mathrm{Pht} 2$

Table 3. UV-Vis spectral data of chromium complexes in DMSO

\begin{tabular}{cc}
\hline Complexes & $\lambda_{\max } \mathrm{nm}(\log \varepsilon)$ \\
\hline \multirow{2}{*}{$\mathrm{Cr} / \mathrm{H}_{2} \mathrm{Pht} 1$} & $552.5(2.487), 495(2.382), 526.5(1.762), 520.0(1.762), 516.5(1.758)$, \\
& $586.5(1.387), 461.0(1.341), 443.5(1.197), 344.5(0.462), 338.5(0.457)$ \\
$\mathrm{Cr} / \mathrm{H}_{2} \mathrm{Pht} 2$ & $552.5(2.485), 495(2.402), 526.0(1.883), 517.0(1.871), 459.5(1.418)$, \\
& $419.5(1.013), 344.5(0.504), 337.0(0.486), 306.0(0.486), 299.0(0.480)$ \\
\hline
\end{tabular}

Fourier transform infrared spectrophotometery (FTIR)

The infrared spectra of solid samples were recorded in $\mathrm{KBr}$ pellets in the region 4000$400 \mathrm{~cm}^{-1}$ on Perkin Elmer spectrum-2000, Fourier Transform Infrared (FTIR) spectrometer in auto mode in the Department of Applied Chemistry, Indian School of Mines University, Dhanbad, India.

The FTIR spectra were taken in auto mode and peak assignments are given in Table 4. The FTIR spectra of complexes $\mathrm{Cr} / \mathrm{H}_{2} \mathrm{Pht} 1$ and $\mathrm{Cr} \backslash \mathrm{H}_{2} \mathrm{Pht} 2$ are shown in Figure 3-4 respectively.

Table 4. Peak assignments of FTIR of complexes

\begin{tabular}{ccccccc}
\hline Complexes & $\begin{array}{c}v \\
(\mathrm{C}=\mathrm{O})\end{array}$ & $\begin{array}{c}v \\
(\mathrm{CO})\end{array}$ & $v(-\mathrm{COO})$ & $v(\mathrm{CrO})$ & $v \mathrm{OH}$ & $\begin{array}{c}\delta(\mathrm{OC}=\mathrm{O})+v \\
(\mathrm{Cr}-\mathrm{O})\end{array}$ \\
\hline $\mathrm{Cr} / \mathrm{H}_{2} \mathrm{Pht} 1$ & 1619 & 1301 & $1419,1493,1446$ & 658,533 & 3402 & 756 \\
$\mathrm{Cr} / \mathrm{H}_{2} \mathrm{Pht} 2$ & 1619 & 1298 & $1415,1492,1546$ & 657,531 & 3403 & 754 \\
\hline
\end{tabular}




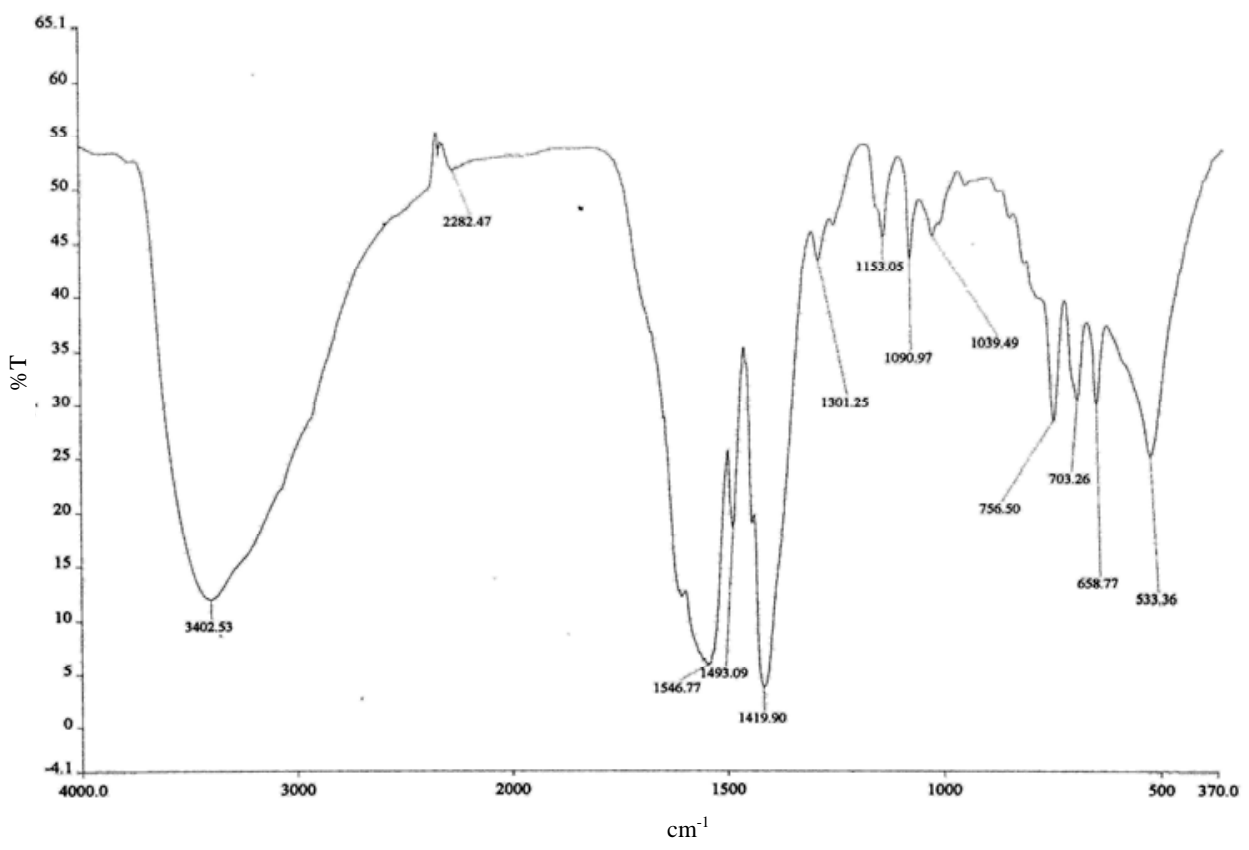

Figure 3. FTIR spectrum of $\mathrm{Cr} / \mathrm{H}_{2} \mathrm{Pht} 1$

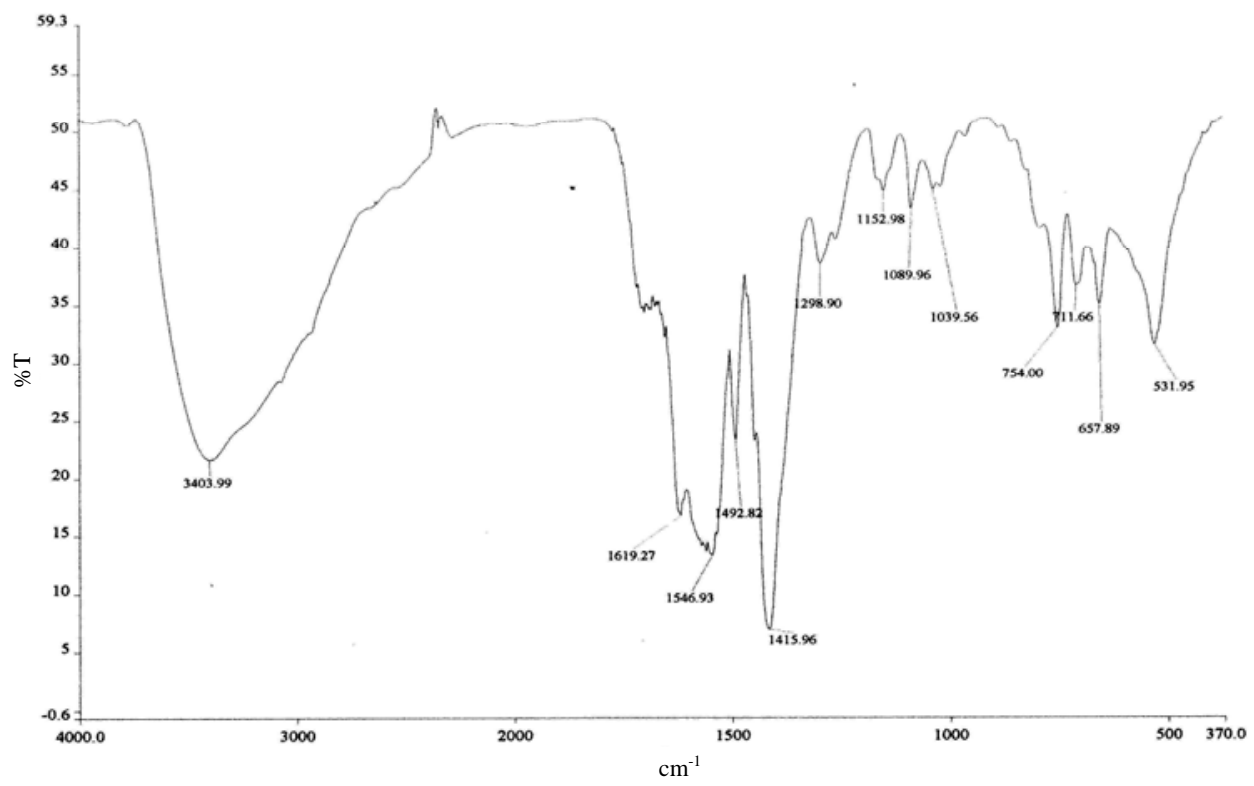

Figure 4. FTIR spectrum of $\mathrm{Cr} / \mathrm{H}_{2} \mathrm{Pht} 2$

Proton nuclear magnetic resonance $\left({ }^{1} H\right.$ NMR) spectrometry

The ${ }^{1} \mathrm{H}$ NMR spectra of complexes were recorded on Bruker DRX-300 instruments in DMSO using Tetramethylsilane (TMS) as an internal standard at Sophisticated Analytical Instrument Facility (SAIF), Central Drug Research Institute and Lucknow, India. 
The proton resonance spectral $\left({ }^{1} \mathrm{H}\right.$ NMR) data of complexes $\mathrm{Cr} / \mathrm{H}_{2} \mathrm{Pht} 1 \mathrm{and} \mathrm{Cr} / \mathrm{H}_{2} \mathrm{Pht} 2$ are shown in Figure 5-6 respectively. ${ }^{1} \mathrm{H}$ NMR spectral data of complexes and their assignments are given in Table 5 .

Table 5. ${ }^{1} \mathrm{H}$ NMR spectral data of complexes and their assignments

\begin{tabular}{lc}
\hline Complexes & Assignments, $\delta$ \\
\hline $\mathrm{Cr} / \mathrm{H}_{2} \mathrm{Pht} 1$ & $7.88-7.53(4 \mathrm{H}, \mathrm{ArH}), 3.33(-\mathrm{OH}),(2.05-2.50)$ Protio solvent component \\
$\mathrm{Cr} / \mathrm{H}_{2} \mathrm{Pht} 2$ & $7.88-7.54(4 \mathrm{H}, \mathrm{ArH}), 3.65(-\mathrm{OH}), 2.72-2.27$ (Protio solvent component) \\
\hline
\end{tabular}

MRPW-1

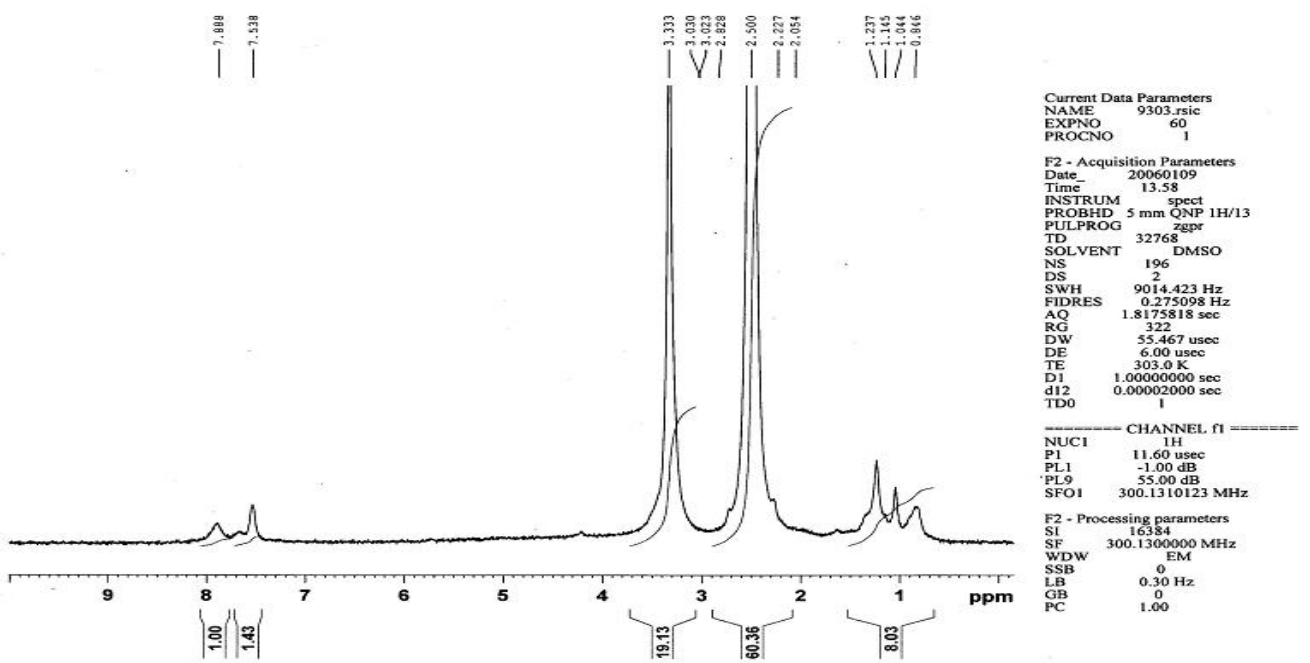

Figure 5. ${ }^{1} \mathrm{H}$ NMR spectrum of $\mathrm{Cr} / \mathrm{H}_{2} \mathrm{Pht} 1$

MRPW-2

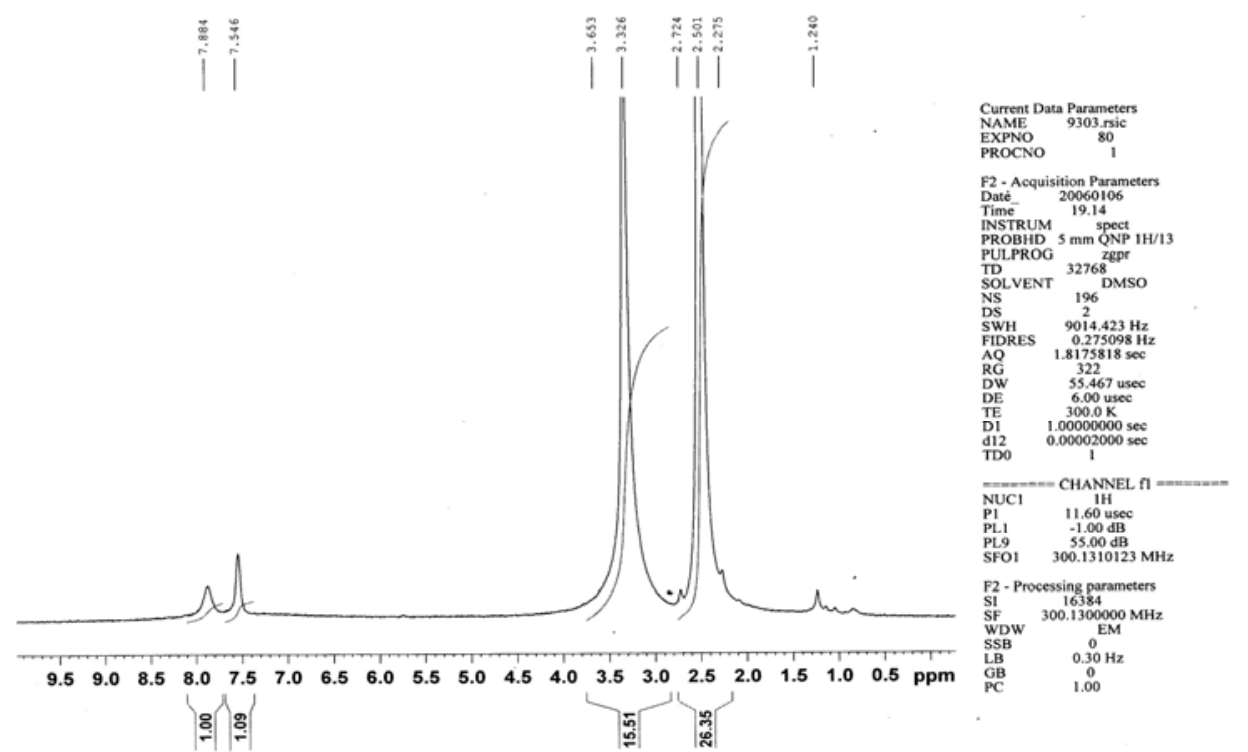

Figure 6. ${ }^{1} \mathrm{H}$ NMR spectrum of $\mathrm{Cr} / \mathrm{H}_{2} \mathrm{Pht} 2$ 
Fast atomic bombardment (FAB) mass spectroscopy

The FAB spectra were recorded on Jeol SX-102 (FAB) mass spectrometer instruments at Sophisticated Analytical Instrument Facility (SAIF), Central Drug Research Institute and Lucknow, India

The FAB Mass spectra, of complexes $\mathrm{Cr} / \mathrm{H}_{2} \mathrm{Pht} 1$ and $\mathrm{Cr} / \mathrm{H}_{2} \mathrm{Pht} 2$ are shown in Figure 7-8 respectively and their expected fragmentation species are given in Table 6-7 respectively.The results from FAB Mass spectra were inferred on the basis as followed by Barnwal et al., ${ }^{9}$ on oxo-bridge multinuclear chromium assemblies like trinuclear complex $\left[\mathrm{Cr}_{3} \mathrm{O}(\mathrm{acac})_{3}\left(\mathrm{OCCC}_{15} \mathrm{H}_{31}\right)_{3}\right]$.

$\mathrm{Cr} / \mathrm{H}_{2} \mathrm{Pht} 1\left[\mathrm{Cr}\left(\mathrm{C}_{8} \mathrm{H}_{5} \mathrm{O}_{4}\right)(\mathrm{OH})_{2}\left(\mathrm{H}_{2} \mathrm{O}\right)_{3}\right]$ Anal: found C, 30.89; H, 4.10; Cr, 16.37 Calcd. For $\mathrm{C}_{8} \mathrm{H}_{13} \mathrm{Cr} \mathrm{O}_{9}$ : C, 31.48; H, 4.26; Cr, 17.05

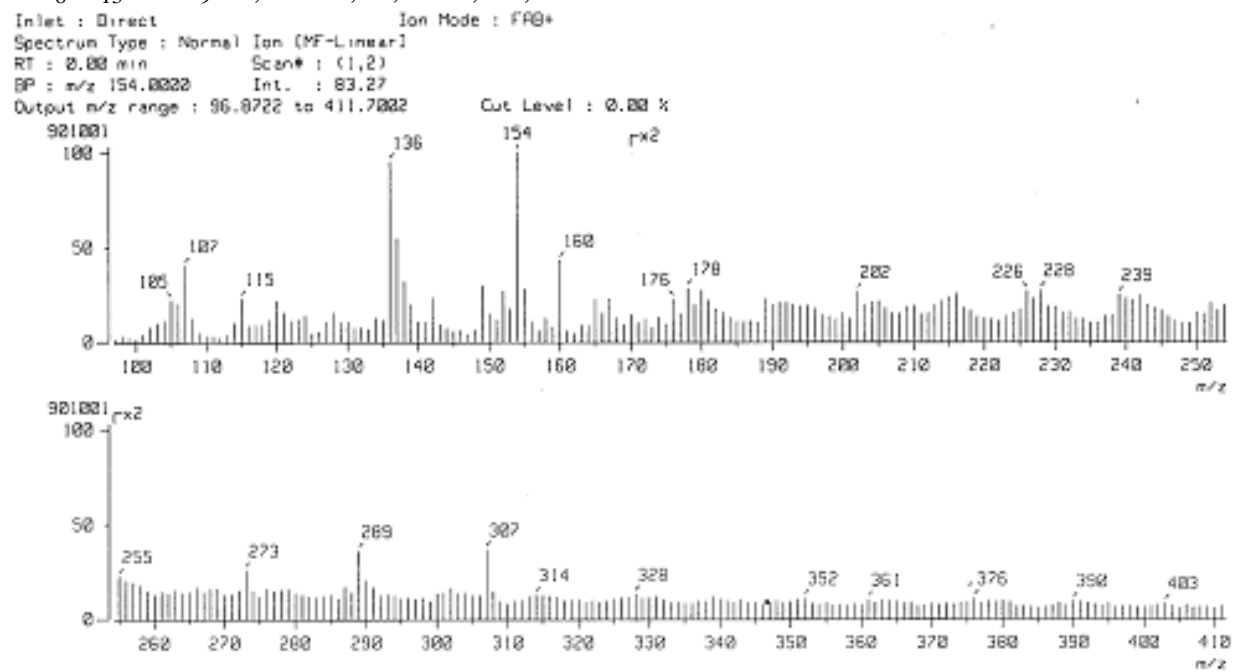

Figure 7. FAB Mass Spectrum of $\mathrm{Cr} / \mathrm{H}_{2} \mathrm{Pht} 1$

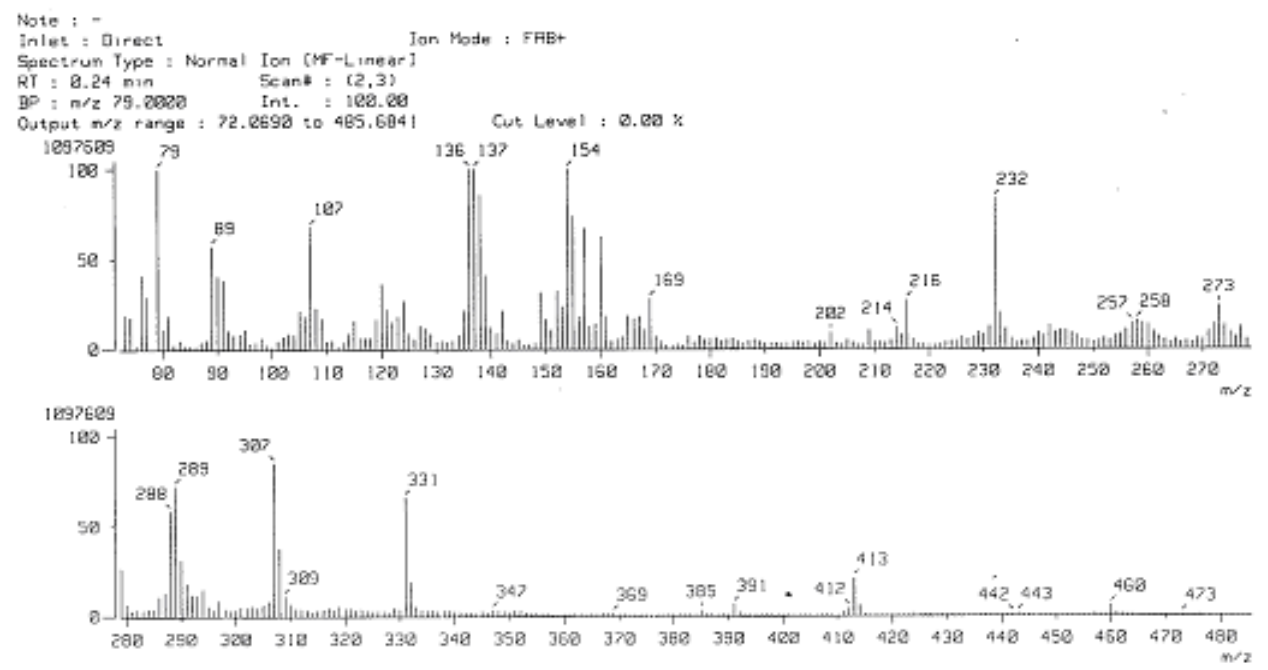

Figure 8. FAB Mass Spectrum of $\mathrm{Cr} / \mathrm{H}_{2} \mathrm{Pht} 2$ 
Table 6. FAB Mass data of complex $\mathrm{Cr} / \mathrm{H}_{2} \mathrm{Pht} 1$

\begin{tabular}{ccc}
\hline Peak position & Expected fragmentation species & Calculated Mass \\
\hline 307 & $\mathrm{Cr}\left(\mathrm{C}_{8} \mathrm{H}_{5} \mathrm{O}_{4}\right)(\mathrm{OH})_{2}\left(\mathrm{H}_{2} \mathrm{O}\right)_{3}$ & 305 \\
289 & $\mathrm{Cr}\left(\mathrm{C}_{8} \mathrm{H}_{5} \mathrm{O}_{4}\right)(\mathrm{OH})_{2}\left(\mathrm{H}_{2} \mathrm{O}\right)_{2}$ & 287 \\
273 & $\mathrm{Cr}\left(\mathrm{C}_{8} \mathrm{H}_{5} \mathrm{O}_{4}\right)(\mathrm{OH})_{2}\left(\mathrm{H}_{2} \mathrm{O}\right)$ & 269 \\
202 & $\mathrm{Cr}\left(\mathrm{C}_{8} \mathrm{H}_{5} \mathrm{O}_{3}\right)$ & 201 \\
154 & $\mathrm{Cr}\left(\mathrm{COC}_{3} \mathrm{H}_{5}\right)$ & 157 \\
105 & $\mathrm{CoC}_{6} \mathrm{H}_{5}$ & 105 \\
\hline
\end{tabular}

Table 7. FAB Mass data of complex $\mathrm{Cr} / \mathrm{H}_{2} \mathrm{Pht} 2$

\begin{tabular}{ccc}
\hline Peak Position & Expected fragmentation species & Calculated mass \\
\hline 331 & $\mathrm{Cr}\left(\mathrm{C}_{8} \mathrm{H}_{5} \mathrm{O}_{4}\right)(\mathrm{OH})_{2}\left(\mathrm{H}_{2} \mathrm{O}\right)_{3} \mathrm{H}_{2} \mathrm{O}$ & 323 \\
307 & $\mathrm{Cr}\left(\mathrm{C}_{8} \mathrm{H}_{5} \mathrm{O}_{4}\right)(\mathrm{OH})_{2}\left(\mathrm{H}_{2} \mathrm{O}\right)_{3}$ & 305 \\
288 & $\mathrm{Cr}\left(\mathrm{C}_{8} \mathrm{H}_{5} \mathrm{O}_{4}\right)(\mathrm{OH})_{2}\left(\mathrm{H}_{2} \mathrm{O}\right)_{2}$ & 287 \\
273 & $\mathrm{Cr}\left(\mathrm{C}_{8} \mathrm{H}_{5} \mathrm{O}_{4}\right)(\mathrm{OH})_{2}\left(\mathrm{H}_{2} \mathrm{O}\right)$ & 269 \\
232 & $\mathrm{Cr}\left(\mathrm{C}_{8} \mathrm{H}_{5} \mathrm{O}_{4}\right)(\mathrm{OH})$ & 234 \\
216 & $\mathrm{Cr}_{\left(\mathrm{C}_{8} \mathrm{H}_{5} \mathrm{O}_{4}\right)}$ & 217 \\
154 & $\mathrm{Cr}\left(\mathrm{OCC}_{6} \mathrm{H}_{6}\right)$ & 157 \\
107 & $\mathrm{COC}_{6} \mathrm{H}_{5}$ & 105 \\
79 & $\mathrm{C}_{6} \mathrm{H}_{5}$ & 77 \\
\hline
\end{tabular}

Calculated mol wt of complex: 305 observed molecular ion peak $(\mathrm{m} / \mathrm{z})$ : 307 . The difference in molecular weight may correspond to the associated $2 \mathrm{H}^{+}$fragments

$\mathrm{Cr} / \mathrm{H}_{2} \mathrm{Pht} 2$ [Cr $\left.\left(\mathrm{C}_{8} \mathrm{H}_{5} \mathrm{O}_{4}\right)(\mathrm{OH})_{2}\left(\mathrm{H}_{2} \mathrm{O}\right)_{3}\right] \mathrm{H}_{2} \mathrm{O}$ Anal: found C, 30.28; $\mathrm{H}, 4.84 ; \mathrm{Cr}, 16.81$ Calcd. For $\mathrm{C}_{8} \mathrm{H}_{15} \mathrm{Cr} \mathrm{O}_{10}$ : C, 29.72; H, 4.64; Cr, 16.10

Calculated mol. wt of complex: 323 Observed molecular ion peak $(\mathrm{m} / \mathrm{z}): 331$. The difference in molecular weight may correspond to the associated half molecule of water.

\section{Differential scanning calorimetry (DSC)}

DSC of chromium complexes, was carried out on the Perkin Elmer's DSC-7 at Department of Applied Chemistry, Indian School of Mines University, Dhanbad, India In each case the following methods was used:

Sample pan: Aluminium (perforated); Scan rate: $50{ }^{\circ} \mathrm{C} / \mathrm{Min}$; Start temperature: $50^{\circ} \mathrm{C}$ End temperature: $450{ }^{\circ} \mathrm{C}$; Purge gas: Nitrogen (at the rate of $20 \mathrm{~mL} / \mathrm{min}$ at the exist). The following Perkin Elmer's DSC software were used for the purpose: Standard (Version 2.1 \& 3.1); Kinetics (3.1); Auto mode (3.1); The DSC was calibrated using indium and zinc as standard.

DSC thermograms of complexes $\mathrm{Cr} / \mathrm{H}_{2} \mathrm{Pht} 1$ and $\mathrm{Cr} \backslash \mathrm{H}_{2} \mathrm{Pht} 2$ are shown in Figure 9-12 respectively. Their kinetic parameters are given in Table 8.

Table 8. Kinetic parameters of complexes obtained from DSC thermogram.

\begin{tabular}{ccccccc}
\hline Complexes & $\begin{array}{c}\text { Temp. range } \\
{ }^{0} \mathrm{C}\end{array}$ & $\begin{array}{c}\text { Peak } \\
\text { Temp. } \\
{ }^{0} \mathrm{C}\end{array}$ & lnKo & $\begin{array}{c}\text { Change in } \\
\text { enthalpy } \\
\Delta \mathrm{H}(\mathrm{J} / \mathrm{g})\end{array}$ & $\begin{array}{c}\text { Activation } \\
\text { energy, } \\
\mathrm{kJ} / \mathrm{mol}\end{array}$ & $\begin{array}{c}\text { Order } \\
\text { of } \\
\text { reaction }\end{array}$ \\
\hline $\mathrm{Cr} / \mathrm{H}_{2} \mathrm{Pht} 1 \mathrm{~A}$ & $75.93-187.50$ & 123.75 & $17.05 \pm 0.36$ & 173.21 & $69.27 \pm 1.49$ & $1.44 \pm 0.03$ \\
$\mathrm{Cr} / \mathrm{H}_{2} \mathrm{Pht} 1 \mathrm{~B}$ & $191.66-348.92$ & 248.25 & $7.85 \pm 0.16$ & -60.48 & $54.51 \pm 1.17$ & $1.19 \pm 0.2$ \\
$\mathrm{Cr} / \mathrm{H}_{2} \mathrm{Pht} 2 \mathrm{~A}$ & $69.37-152.36$ & 105.75 & $20.71 \pm 0.44$ & 78.59 & $76.82 \pm 1.65$ & $1.34 \pm 0.02$ \\
$\mathrm{Cr} / \mathrm{H}_{2} \mathrm{Pht} 2 \mathrm{~B}$ & $350.54-400.1$ & 387.15 & $55.96 \pm 1.2$ & -10.27 & $323.69 \pm 6.99$ & $0.54 \pm 0.01$ \\
\hline
\end{tabular}




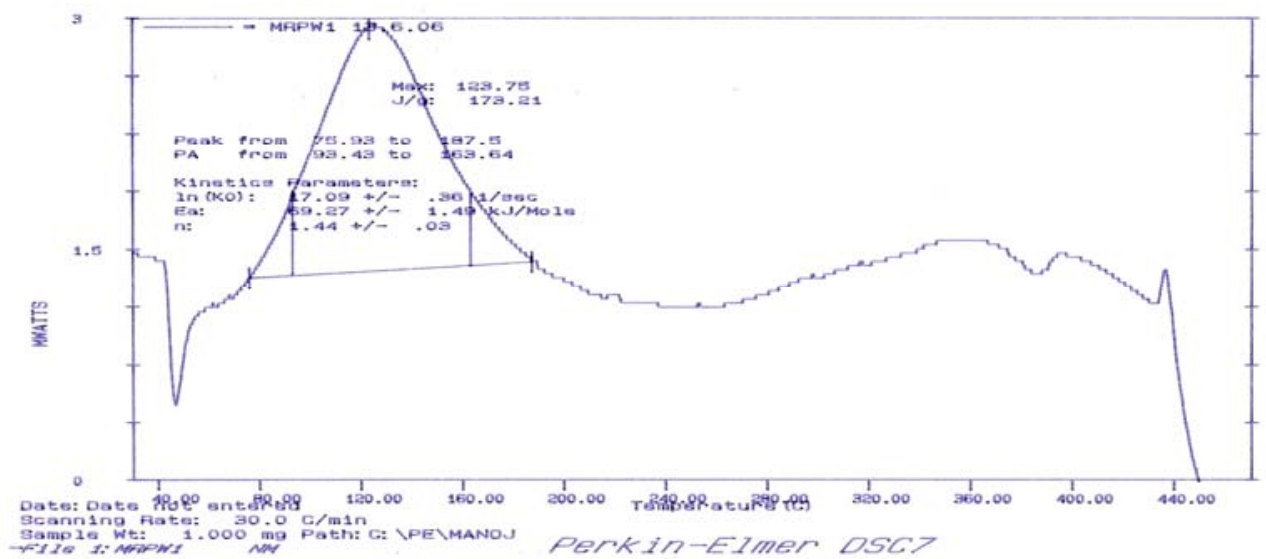

Figure 9. DSC thermogram of $\mathrm{Cr} / \mathrm{H}_{2} \mathrm{Pht} 1 \mathrm{~A}$

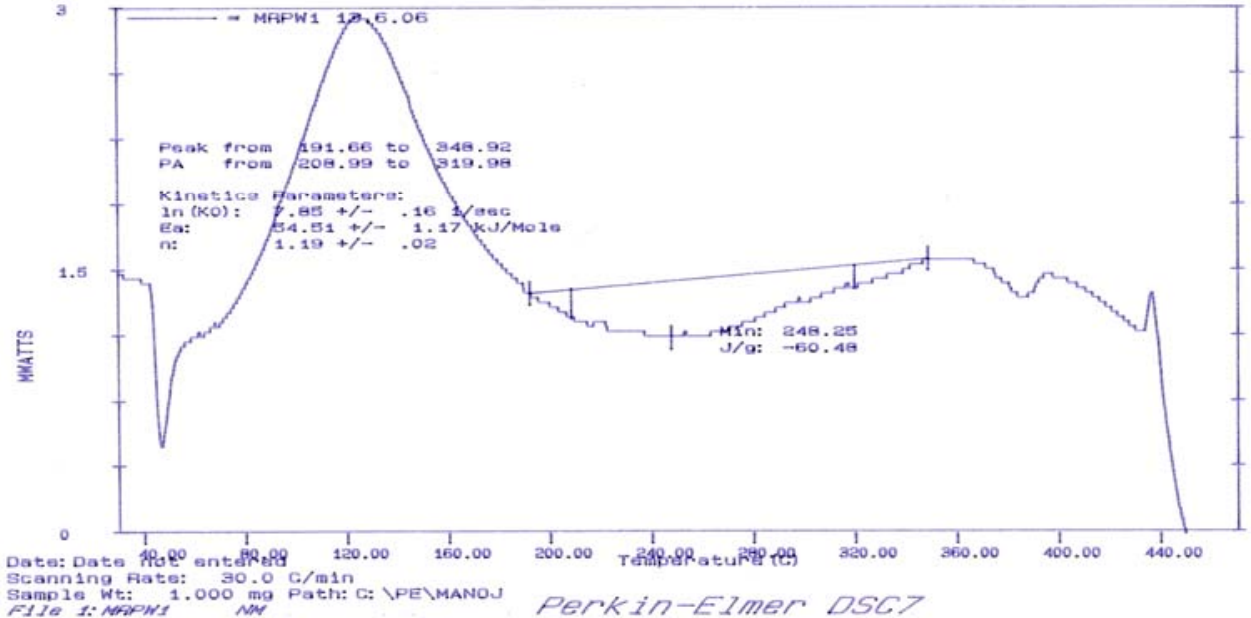

Figure 10. DSC thermogram of $\mathrm{Cr} / \mathrm{H}_{2} \mathrm{Pht} 1 \mathrm{~B}$

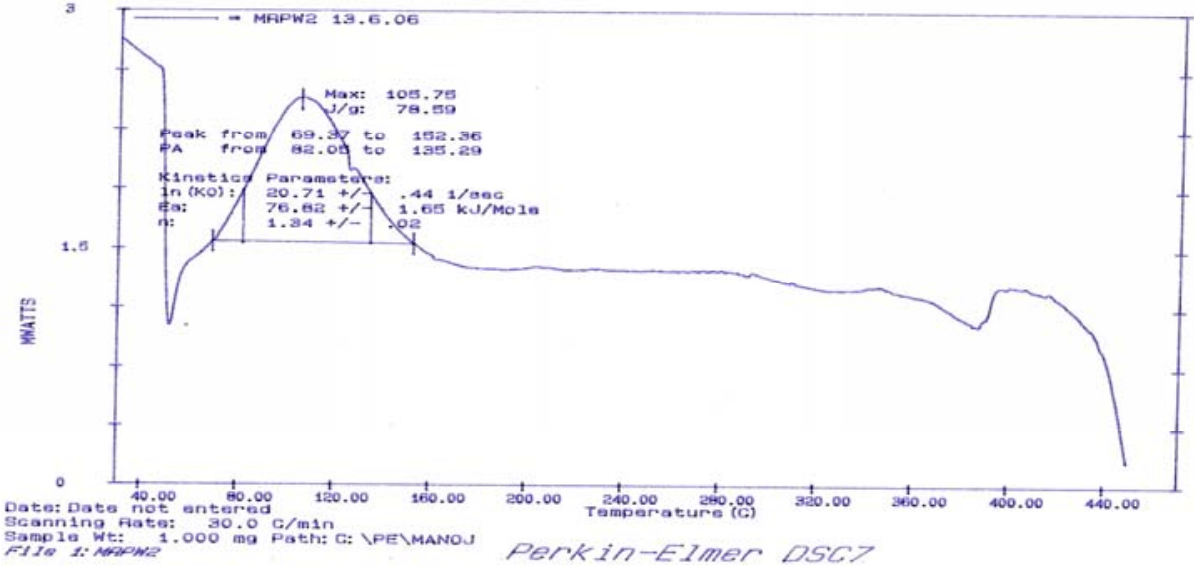

Figure 11. DSC thermogram of $\mathrm{Cr} / \mathrm{H}_{2} \mathrm{Pht} 2 \mathrm{~A}$ 


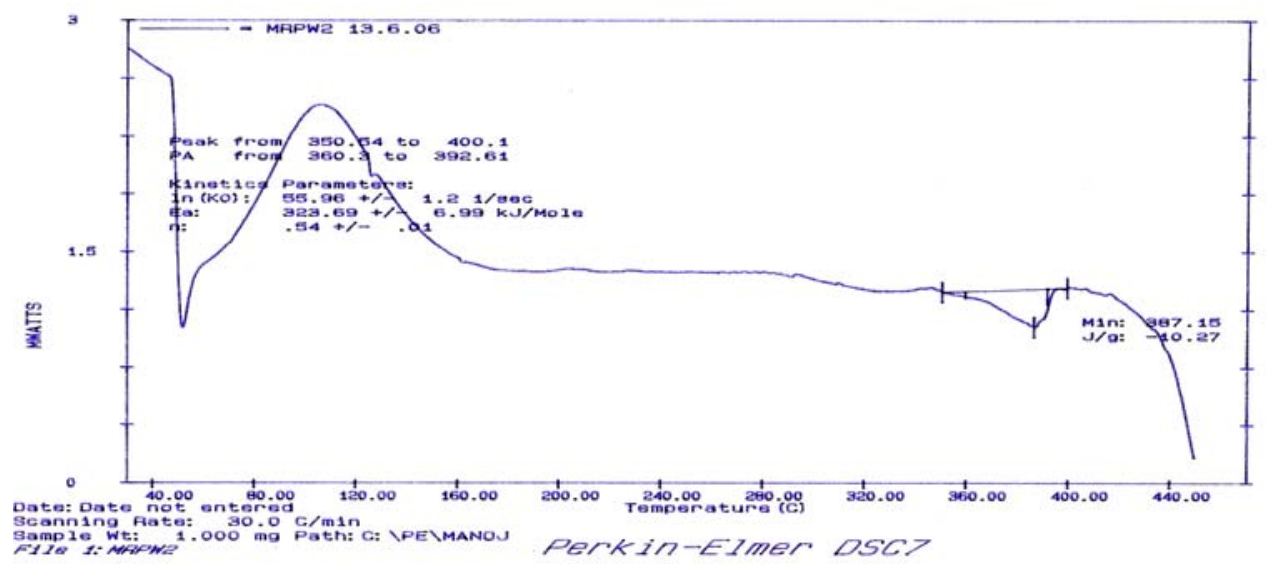

Figure 12. DSC thermogram of $\mathrm{Cr} / \mathrm{H}_{2} \mathrm{Pht} 2 \mathrm{~B}$

\section{Results and Discussion}

The physical and analytical parameters of $\mathrm{Cr} / \mathrm{H}_{2} \mathrm{Pht}$ complexes are summarized in Table 2 and are in agreement with the proposed molecular formula for the complexes. In the UV Vis spectra of both complexes, the bands observed at 495 and $553 \mathrm{~nm}$ lie in the region of the ${ }^{4} \mathrm{~A}_{2} \mathrm{~g} \rightarrow{ }^{4} \mathrm{~T} 1 \mathrm{~g}$ and ${ }^{4} \mathrm{~A} 2 \mathrm{~g} \rightarrow{ }^{4} \mathrm{~T}_{2} \mathrm{~g}$ d-d transitions of octahedral chromium complexes ${ }^{10,11}$.

FTIR spectroscopic analysis also confirms the structure of the complexes. FTIR bands of phthalic acid with that of $\mathrm{Cr} / \mathrm{H}_{2} \mathrm{Pht}$ complexes shows a slight shifting of bands, due to the strong electropositivity of metal ion compared to that of portion in acid. The band at $1619 \mathrm{~cm}^{-1}$ are attributed to $\mathrm{C}=\mathrm{O}$ stretching of complexes ${ }^{12}$.

FTIR spectra of complexes formed indicated the presence of coordinated water molecules in the complexes and ortho-disubstitution in both the complexes. Disappearance of the absorption bands of the phthalic acid due to $\mathrm{O}-\mathrm{H}$ of the carboxyl group in the range $3007-2525 \mathrm{~cm}^{-1}$ and $3240-2594 \mathrm{~cm}^{-1}$ respectively, indicated deprotonation of the acidic group of the ligands and appearance of new bands in the region $600-700 \mathrm{~cm}^{-1}$ in the spectra of both the complexes were attributed to $v(\mathrm{Cr}-\mathrm{O})$. Thus FTIR results suggested coordination of oxygen atom to the metal ion and indicated formation of new complex ${ }^{13}$.

${ }^{1} \mathrm{H}$ NMR of $\mathrm{Cr} / \mathrm{H}_{2} \mathrm{Pht}$ complexes showed that deprotonation of only one - $\mathrm{COOH}$ group of the phthalic acid took place and the complex formed was not through the $-\mathrm{OH}$ of the acid. Both the complexes show resonance at 2.05-2.72 ppm, which may be for the presence of protio- solvent component ${ }^{14}$.

DSC thermogram of $\mathrm{Cr} / \mathrm{H}_{2} \mathrm{Pht}$ complexes showed the values of kinetic parameters enthalpy $(\Delta \mathrm{H})$, activation energy $(\mathrm{Ea})$, lnKo and order of reaction (n) for the dehydration and decomposition of the dehydrated complexes. The values of activation energy are useful for the comparison of the thermal stability of these compounds.

The activation energy of $\mathrm{Cr} / \mathrm{H}_{2}$ pht1 and $\mathrm{Cr} / \mathrm{H}_{2}$ pht 2 complexes were found to be 54.51$69.27 \mathrm{~kJ} / \mathrm{mol}$ and $76.82-323.69 \mathrm{~kJ} / \mathrm{mol}$ respectively. The first step decomposition of the complex $\mathrm{Cr} / \mathrm{H}_{2}$ pht1 showed $69.27 \mathrm{~kJ} / \mathrm{mol}$, activation energy in the temperature $64.78{ }^{\circ} \mathrm{C}$ to $177{ }^{\circ} \mathrm{C}$ while in the second step decomposition showed $54.51 \mathrm{~kJ} / \mathrm{mol}$, activation energy in the temperature range $191.66-348.92{ }^{\circ} \mathrm{C}$. The first step decomposition of the complex $\mathrm{Cr} / \mathrm{H}_{2} \mathrm{pht} 2$ showed $76.82 \mathrm{~kJ} / \mathrm{mol}$, activation energy in the temperature $69.37-152.36{ }^{\circ} \mathrm{C}$. 
In $\mathrm{Cr} / \mathrm{H}_{2} \mathrm{Pht}$ complexes, low value of activation energy ${ }^{8}$ of the first and second step decomposition indicated lability of the complex. DSC studies indicated that the $\mathrm{Cr} / \mathrm{H}_{2} \mathrm{Pht}$ complexes may be stable at ambient temperature may be labile at higher temperature.

\section{Conclusion}

Complexes $\left[\mathrm{Cr}\left(\mathrm{C}_{8} \mathrm{H}_{5} \mathrm{O}_{4}\right)(\mathrm{OH})_{2}\left(\mathrm{H}_{2} \mathrm{O}\right)_{3}\right]$ and $\left[\mathrm{Cr}\left(\mathrm{C}_{8} \mathrm{H}_{5} \mathrm{O}_{4}\right)(\mathrm{OH})_{2}\left(\mathrm{H}_{2} \mathrm{O}\right)_{3}\right] \mathrm{H}_{2} \mathrm{O}$ were prepared by using chromium trioxide $\left(\mathrm{CrO}_{3}\right)$ and phthalic acid. FTIR spectra of complexes formed indicated the presence of coordinated water molecules and ortho-disubstitution in both the complexes. ${ }^{1} \mathrm{H}$ NMR of $\mathrm{Cr} / \mathrm{H}_{2} \mathrm{Pht}$ complexes showed that deprotonation of only one $-\mathrm{COOH}$ group of the phthalic acid took place and the complex formed was not through the $-\mathrm{OH}$ of the acid. FAB-Mass results showed the complexes $\mathrm{Cr} / \mathrm{H}_{2} \mathrm{Pht} 1$ and $\mathrm{Cr} / \mathrm{H}_{2} \mathrm{Pht} 2$ featured monodentate $\mathrm{HPht}^{-}$and $\mathrm{OH}^{-}$ligands and both the complexes are probably monomeric. DSC thermogram of $\mathrm{Cr} / \mathrm{H}_{2} \mathrm{Pht}$ complexes showed, low value of activation energy of the first and second step decomposition, indicated lability of the complexes.

\section{References}

1. Borisova N E, Rehetova M D and Ustynyuk Y A, Chem Rev., 2007, 107(1), 46-79; DOI:10.1021/cr0683616

2. Shokrollahi A, Ghaedi M, Montazerozohori M, Kianfar A H, Ghaedi H, Khanjari N, Noshadi S and Joybar S, J Chem., 2011, 8(2), 495-506; DOI:10.1155/2011/437621

3. Bayoumi Hoda A, Abdel Nasser M A Alaghaz and Mutlak Sh Aljahdali, Int $J$ Electrochem Sci., 2013, 8, 9399-9413.

4. Anet F A and Leblanc E, J Am Chem Soc., 1957, 79(10), 2649-2650; DOI:10.1021/ja01567a080

5. Khan Zaheer and Islamia Mohammad Millia, Indian J Chem., 2004, 42A, 1060-1065.

6. Bilehal Dinesh, Kulkarni Raviraj and Nadibewoor Sharanappa, J Molecular Catal A: Chem., 2005, 232(1-2), 21-28; DOI:10.1016/j.molcata.2005.01.020

7. Mishra M K and Misra N M, J Chem., 2011, 8(2), 513-516; DOI:10.1155/2011/215012

8. Goshe Andrew J, Steele Ian M, Ceccarelli Christopher, Rheingold Arnold L and Bosnich B, PNAS, 2002, 99(8), 4823-4829; DOI:10.1073/pnas.052587499

9. Baranwal B P and Fatma Talat, J Molecular Struct., 2005, 750(1-3), 72-77; DOI:10.1016/j.molstruc.2005.03.050

10. Arenas J F and Marcos J I, Spectrochim Acta Part A: Mole Biomole Spectr., 1980, 36(12), 1075-1081; DOI:10.1016/0584-8539(80)80096-1

11. Vasovic D and Stojakovic D J, J Coord Chem., 1988, 17(4), 325-330; DOI:10.1080/00958978808073924

12. Hewkin D J and Griffith W P, J Chem Soc A, 1966, 472-475; DOI:10.1039/J19660000472

13. Bellamy L J, The Infrared Spectrum of complex molecules, Third Ed., Chapman and Hall Ltd London, 1975.

14. Broadhurst C L, Schmidt W F, Reeves J B, Polansky M M, Gautschi K and Anderson R A, J Inorg Biochem., 1997, 66(2), 119-130; http://dx.doi.org/10.1016/S0162-0134(96)00192-4 